Article

\title{
Microwave-assisted ionothermal synthesis of hierarchical microcube-like BiOBr with enhanced photocatalytic activity
}

\author{
Yingchun Miao a,b,*, Zichao Lian b, Yuning Huo b, Hexing Li b,\# \\ a Faculty of Chemical and Environmental Science, Key Laboratory of Environment Chemistry, Qujing Normal University, Qujing 655000, Yunnan, China \\ b The Education Ministry Key Laboratory of Resource Chemistry, Shanghai Key Laboratory of Rare Earth Functional Materials, Shanghai Normal \\ University, Shanghai 200234, China
}

\section{A R T I C L E I N F}

\section{Article history:}

Received 3 March 2018

Accepted 25 April 2018

Published 5 August 2018

\section{Keywords:}

Microwave

BiOBr microcubes

Self-assembly

Photocatalytic degradation

Mineralization ability

\begin{abstract}
A B S T R A C T
Bismuth oxybromide (BiOBr) with a hierarchical microcube morphology was successfully synthesized via microwave-assisted ionothermal self-assembly method. The as-obtained BiOBr was composed of regular multi-layered nanosheets, which were formed by selective adsorption of ionic liquids on the Br-terminated surface, followed by the formation of hydrogen bond-co- $\pi$ - $\pi$ stacking. The synthesized BiOBr exhibited high activity, excellent stability, and superior mineralization ability in the photocatalytic degradation of organic dyes under visible light owing to its enhanced light absorbance and narrow bandgap. Furthermore, photo-generated electrons were determined to be the main active species by comparison with different trapping agents used in the photocatalytic reactions.
\end{abstract}

(C) 2018, Dalian Institute of Chemical Physics, Chinese Academy of Sciences. Published by Elsevier B.V. All rights reserved.

\section{Introduction}

Recently, microwave-assisted ionothermal synthesis has received considerable attention owing to its rapid volumetric heating, high reaction rate, short reaction time, enhanced product selectivity, environmental friendliness, and energy efficiency compared to conventional heating routes $[1,2]$. Meanwhile, ionic liquids (ILs) have been found to display high fluidity, low melting temperature, extended liquid-state temperature ranges, high ionic conductivity, ability to dissolve in various materials, and absent measurable vapor pressure $[3,4]$. In particular, ILs are good media for microwave absorption, leading to a high heating rate because of the presence of many organic positive ions with a high polarizability [5]. To date, various functional materials have been synthesized by the microwave-assisted ionothermal method, including nanorods, nanowires, and hollow microspheres [6-13].

As is well known, photocatalysis is a powerful strategy for environmental cleaning via decomposition of organic pollutants or for $\mathrm{H}_{2}$ production by water splitting [14,15]. Bismuth oxybromide (BiOBr) has received considerable attention due to its narrow energy bandgap for absorbing visible light, low photo-induced electron-hole recombination, nontoxicity, and strong oxidizing power [16-22]. Although various $\mathrm{BiOBr}$ photocatalysts have been synthesized by traditional solvothermal methods [23-27], the development of new, green, and efficient

\footnotetext{
*Corresponding author. E-mail: miaoyingchun1979@sohu.com

\# Corresponding author. E-mail: hexing-li@shnu.edu.cn

This work was supported by the National Natural Science Foundation of China (20937003, 21261140333, 21237003, 21207091, 21577092, 2171101231), Shanghai Government (12230706000, 11JC1409000, 12YZ091, 15520711300), Yunnan Applied Basic Research Project of Province (2013FZ109, 2016FB016), and Key Projects of Yunnan Provincial Department of Education (2015Z183, 2016ZZX207).

DOI: 10.1016/S1872-2067(18)63080-3 | http://www.sciencedirect.com/science/journal/18722067 | Chin. J. Catal., Vol. 39, No. 8, August 2018
} 
synthesis methods to achieve a novel structure is still required.

Herein, we reported for the first time the synthesis of hierarchical BiOBr microcubes by microwave-assisted ionothermal self-assembly method. This method required a short reaction time and could achieve the desired morphology and structure. Moreover, the as-prepared BiOBr exhibited high activity and excellent stability in photocatalytic degradation of organic dyes under visible light owing to its strong light harvesting ability and unique structure.

\section{Experimental}

\subsection{Sample preparation}

In brief, $1.68 \mathrm{~g} \mathrm{Bi}\left(\mathrm{NO}_{3}\right)_{3} \cdot 5 \mathrm{H}_{2} \mathrm{O}$ and the required amount of 1-hexadecyl-3-methylimidazolium-bromide (HB) were dissolved in $30 \mathrm{~mL}$ of ethylene glycol (EG) and magnetically stirred for $30 \mathrm{~min}$ to form a homogenous solution. The molar ratio of $\mathrm{Bi}$ to $\mathrm{Br}$ was controlled to be $0.4,0.8$, and 1.1 in three parallel experiments. The solution was then transferred into a $50 \mathrm{~mL}$ teflon-lined autoclave and heated to $160{ }^{\circ} \mathrm{C}$ by microwaves $(2.45 \mathrm{GHz}, 1000 \mathrm{~W})$. After a desired reaction time, the mixture was cooled to room temperature. The product was separated by filtering, washed with ethanol, dried at $80^{\circ} \mathrm{C}$ in air overnight. The final particles were then annealed at $400{ }^{\circ} \mathrm{C}$ for $4 \mathrm{~h}$ in air to promote crystallization. The as-synthesized $\mathrm{BiOBr}$ was denoted as BiOBr.

For comparison, $\mathrm{BiOBr}$ was also synthesized using 1-octyl-3-methylimidazolium-bromide

1-hexyl-3-methylimidazolium-bromide (hb), a mixture of $\mathrm{KBr}$ and 1-hexadecyl-3-methylimidazolium nitrate (HK), a mixture of $\mathrm{KCl}$ and $\mathrm{HK}$, cetrimonium bromide (CTAB), and a mixture of 1-methyl-imidazolium (MI) and $\mathrm{KBr}$ instead of $\mathrm{HB}$, which were denoted as $\mathrm{BiOBr}(\mathrm{OB}), \mathrm{BiOBr}(\mathrm{hb}), \mathrm{BiOBr}(\mathrm{HK}), \mathrm{BiOCl}(\mathrm{HK})$, $\mathrm{BiOBr}(\mathrm{CTAB})$, and $\mathrm{BiOBr}(\mathrm{MI})$, respectively. Crushed $\mathrm{BiOBr}$ was synthesized by grinding $0.2 \mathrm{~g}$ of the $\mathrm{BiOBr}$ sample and ethanol for 120 min using a pestle and mortar.

\subsection{Characterization}

The crystal structure was investigated by X-ray diffraction (XRD, Rigaku D/Max-2000) and the fine structure was analyzed by Fourier transform infrared (FTIR) spectroscopy (NEXUS 470). The surface morphology was observed by transmission electronic microscopy (TEM, JEM-2010) and field emission scanning electron microscopy (FESEM, HITACHI S-4800); the compositional data of the samples were also recorded using energy dispersive X-ray spectroscopy (EDX). The thermal stability was investigated by a thermogravimetric analysis (TGA, DTG-60H). X-ray photoelectron spectroscopy (XPS, Versa Probe PHI 5000) was employed to determine the surface electronic states. All the binding energy values were calibrated using $\mathrm{C} 1 \mathrm{~s}$ (284.8 eV) as reference. $\mathrm{N}_{2}$ adsorption-desorption isotherms were measured on a TriStar II 3020 at $-196^{\circ} \mathrm{C}$ and the surface area was calculated by applying the Brunauer-Emmett-Teller (BET) model on the desorption branches. The optical properties were determined by ultraviolet-visible diffuse reflectance spectra (UV-Vis DRS, Varian Cary 500). The surface photovoltage spectra (SPS) were measured on a self-designed system consisting of a $500 \mathrm{~W}$ xenon lamp (CHF XM500W, Stusttech) combined with a double-prism monochromator (Omini-500, Zolix) as the light source, a light chopper ( $\sim 23 \mathrm{~Hz}$, SR540, Stanford), and a lock-in amplifier (SR830-DSP, Stanford). The photovoltaic cell had a sandwich structure of ITO-sample-ITO.

\subsection{Photocatalytic activity test}

Photocatalytic degradation was carried out at $30{ }^{\circ} \mathrm{C}$ in a self-designed $250 \mathrm{~mL}$ reactor containing $0.025 \mathrm{~g}$ catalyst and $10.0 \mathrm{mg} / \mathrm{L}$ organic dye in a $100 \mathrm{~mL}$ aqueous solution. A $300 \mathrm{~W}$ Xe lamp was used as the light source, and light with a wavelength shorter than $420 \mathrm{~nm}$ was cut-off using a glass filter (JB-420 nm). During the reaction process, the mixture was sampled at specified time intervals for measuring the concentration of the unreacted dye using a UV-vis spectrophotometer (UV-7504PC) at the characteristic wavelength. The total organic carbon (TOC) was determined on a Vario TOC analyzer. The reproducibility of the results was checked by repeating the experiments at least three times and was found to be within acceptable limits $( \pm 6 \%)$.

\section{Results and discussion}

\subsection{Structural characterization of microcube-like $\mathrm{BiOBr}$}

\subsubsection{FESEM, TEM, XRD, and XPS results}

The FESEM images of BiOBr (Fig. 1(a)-(c)) showed uniform microcubes of $4 \mu \mathrm{m}$ assembled by nanosheets with thicknesses less than $50 \mathrm{~nm}$. The TEM image (Fig. 1(d)) showed a solid
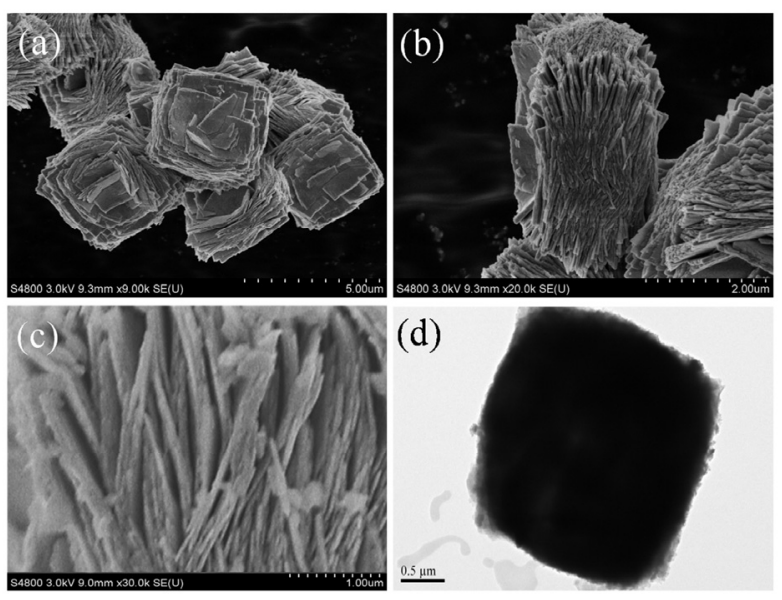

(d)
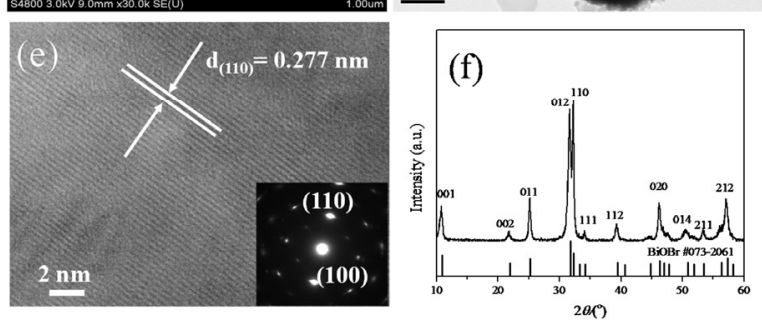

Fig. 1. FESEM (a-c), TEM (d), HRTEM images (e) (inset is the SAED image), and XRD patterns (f) of as-prepared BiOBr. 
microcube. Meanwhile, the high-resolution TEM (HRTEM) image (Fig. 1(e)) demonstrated well-crystallized $\mathrm{BiOBr}$ mesocrystals corresponding to the (110) plane with a lattice spacing of $0.277 \mathrm{~nm}$ [27], which could be further confirmed by the selected area electron diffraction (SAED) patterns with scattered bright spots representing the (110) and (100) lattice planes, indicating tetragonal $\mathrm{BiOBr}$ mesocrystals (inset of Fig. 1(e)). Furthermore, the XRD result (Fig. 1(f)) demonstrated that the as-obtained $\mathrm{BiOBr}$ had a highly crystalline pure tetragonal phase (JCPDS No. 73-2061). In addition, the EDX spectrum (Fig. $\mathrm{S} 1$ ) determined the $\mathrm{Bi} / \mathrm{Br} / 0$ molar ratio to be 1.00:1.00:1.00 in $\mathrm{BiOBr}$, corresponding to the pure stoichiometric ratio of $\mathrm{BiOBr}$. The XPS results (Fig. S2) also confirmed the pure BiOBr phase with a Bi:0:Br molar ratio of 1.26:1.07:1.00 and Bi $4 f, 01 s$, and $\mathrm{Br} 3 d$ binding energies of 164.7/159.4 [28], 530.2 [29], and $68.6 \mathrm{eV}$ [30], respectively.

As shown in Fig. 2, only nanoparticles with a diameter of around $100 \mathrm{~nm}$ were obtained in the early stage. After microwave-assisted IL treatment for $1 \mathrm{~min}$, these nanoparticles grew into separated nanosheets with a thickness of around $20 \mathrm{~nm}$, which could be attributed to the selective adsorption of $\mathrm{HB}$ cations on different facets of $\mathrm{BiOBr}$, leading to priority-orientated two-dimensional (2D) crystal growth. When the reaction time was increased to $30 \mathrm{~min}$, these nanosheets assembled onto the original nanoparticles owing to the high surface energy and surface temperature resulting from the strong adsorption of the microwave, forming flower-like microspheres. Furthermore, at $40 \mathrm{~min}$ microcubes were assembled by the layer-by-layer mechanism due to the growth of the core nanoparticles into nanosheets. Moreover, with increasing quantity of $\mathrm{HB}$, the as-prepared samples transitioned from microspherical $\mathrm{BiOBr}$ superstructures to flower-like structures and then microcube-like $\mathrm{BiOBr}$ with regular nanosheets (Fig. S3). Furthermore, the XRD patterns (Fig. 2(g)) suggested that the microwave-assisted IL method enabled the reaction to be completed within a very short time [31-36], possibly due to the

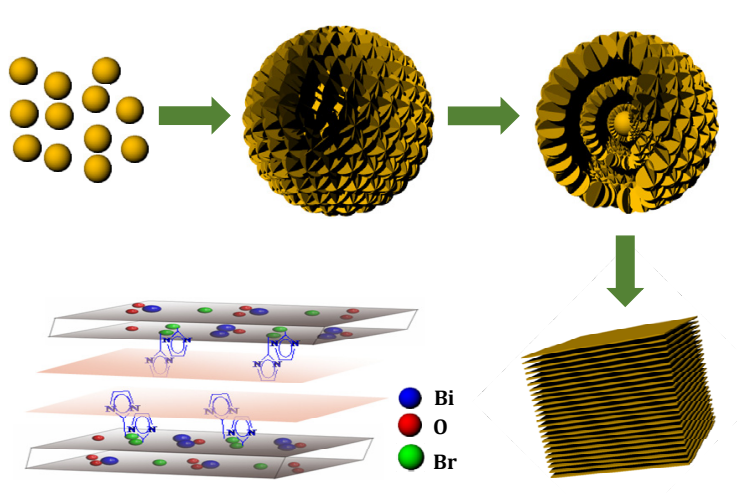

Fig. 3. Scheme of formation of hierarchical BiOBr microcubes under microwave-assisted ionothermal conditions.

strong microwave absorbance caused by the high ionic conductivity and polarizability of HB.

\subsubsection{Formation of $\mathrm{BiOBr}$}

Fig. 3 briefly illustrates the formation of hierarchical $\mathrm{BiOBr}$ microcubes by microwave-assisted ionothermal self-assembly based on the above analysis. The $\left[\mathrm{Bi}_{2} \mathrm{O}_{2}\right]^{2+}$ could be formed via reaction (1) and (2) [29], followed by the formation of $\mathrm{BiOBr}$ nuclei by reaction (3) and (4).

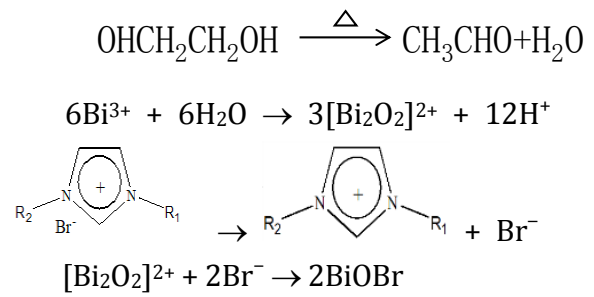

The nanoparticles might stack through the selective adsorption of $\mathrm{HB}$ as the capping agent and mass diffusion. The superior advantage of the ILs could lead to hydrogen bond-co- $\pi-\pi$ stacking in the liquid state [37]. The cations of the ILs could be
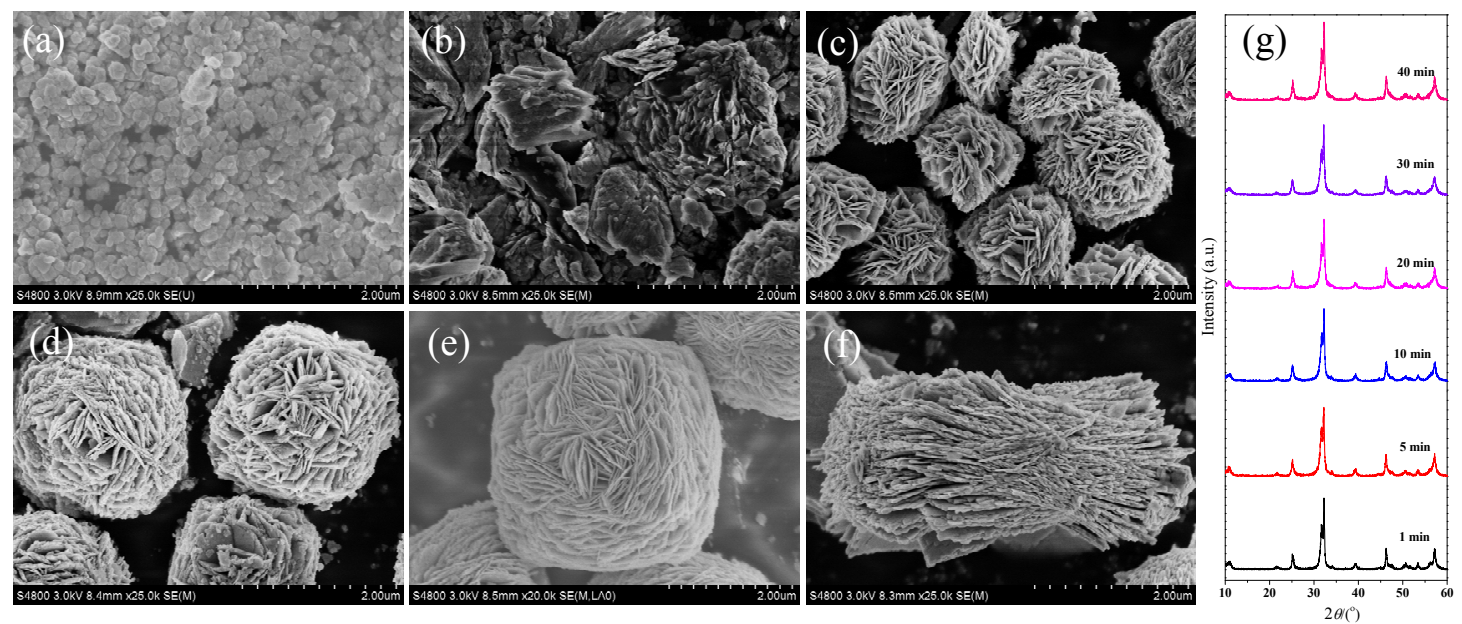

Fig. 2. FESEM images ((a)-(f)) and XRD patterns (g) of formation of BiOBr mesocrystals at different reaction times. (a) 0 min; (b) $1 \mathrm{~min}$; (c) $5 \mathrm{~min}$; (d) $20 \mathrm{~min}$; (e) $30 \mathrm{~min}$; and (f) $40 \mathrm{~min}$. Scale bar: $1 \mu \mathrm{m}$. 
easily adsorbed on the Br-terminated surface by electrostatic forces, and the hydrogen bond formed between the hydrogen atom at the $\mathrm{C} 2$ position of the imidazole ring and the bromine atom of $\mathrm{Br}^{-}$[BiOBr] could act as an effective bridge to connect the Br-terminated plane of the produced metal-oxide nuclei and the cations of the ILs. Also, the IL cations would be aligned by additional $\pi-\pi$ interactions among the imidazolium rings of HB to facilitate the proposed relocation of molecules based on HB's ability to self-assemble into stabilized ordered structures. The hydrogen bond-co- $\pi-\pi$ stacking could decrease the polarity of the selective adsorption surface and thus restrain its microwave absorption ability, retarding the crystal growth of the 2D selective adsorption surface to form a 3D cubic architecture. The $\pi-\pi$ stacking could result in strong cloud density and static repulsion in each nanosheet because the zeta potentials of $\mathrm{Bi}$ $\mathrm{OBr}$ without calcination, $\mathrm{BiOBr}$, and the mixture of $\mathrm{BiOBr}+\mathrm{EG}$ + HB were $-10.5,-0.448$, and $-0.345 \mathrm{mV}$ respectively, which could adjust the intervals of the nanosheet and the thicknesses of the microcubes.

The TGA curve (Fig. S4) revealed a high organic content (ca. $12.7 \%$ by weight) in $\mathrm{BiOBr}$ without calcination. The DRS spectra in Fig. 4(a) revealed that BiOBr displayed a much higher light absorbance than crushed BiOBr (Fig. S5), which could be attributed to the multiple light reflections between the nanosheets in the microcubes. The bandgap obviously widened from 2.56 to $2.66 \mathrm{eV}$ after crushing (inset of Fig. 4(a)). The SPS spectra (Fig. 4(b)) confirmed that $\mathrm{BiOBr}$ without calcination displayed several peaks due to the presence of various organic species. After calcination, only two photovoltaic peaks, corresponding to two discrete valence bands in $\mathrm{BiOBr}$, were observed due to the presence of $02 \mathrm{P}$ and $\mathrm{Br} 4 \mathrm{P}$ orbitals (inset of Fig. 4(b)) [38-40]. This could also account for the spectral responses in both UV and visible regions, which corresponded to an indirect bandgap of $2.56 \mathrm{eV}$ in BiOBr (Fig. 4(a)) [41]. Moreover, the photovoltaic responses of mixed $\mathrm{BiOBr}, \mathrm{EG}$, and $\mathrm{HB}$ were weaker than those of $\mathrm{BiOBr}$ owing to the absence of the hydrogen bond-co- $\pi-\pi$ stacking because $\mathrm{BiOBr}$ was covered by EG and HB, leading to limited light absorption. The FTIR spectra (Fig. S6) displayed significantly different structures for pure $\mathrm{HB}$ and $\mathrm{BiOBr}$ without calcination. We could observe an ab- sorption band at $3077 \mathrm{~cm}^{-1}$, corresponding to the stretching vibration of $\mathrm{C} 2-\mathrm{H}$ in the imidazole ring. Meanwhile, the peaks at 1575,1468 , and $1174 \mathrm{~cm}^{-1}$ were attributed to the skeleton stretching vibration signal of the imidazole ring and became broader and weaker in the FTIR spectra of BiOBr [37]. These results indicated that there were strong interactions between the ILs and $\mathrm{BiOBr}$, confirming the existence of the strong hydrogen bonds in $\mathrm{C} 2(\mathrm{HB})-\mathrm{H}-\mathrm{Br}(\mathrm{BiOBr})$, which was similar to previous results $[37,42]$. Moreover, the peak at $1038 \mathrm{~cm}^{-1}$, characteristic of the $\mathrm{C}-\mathrm{N}$ stretching vibration $\left(\nu_{\mathrm{C}-\mathrm{N}}\right)$ mode in the imidazole ring of $\mathrm{BiOBr}$ without calcination, became narrower and stronger than that observed in the spectra for $\mathrm{HB}$ and $\mathrm{Bi}-$ $\mathrm{OBr}+\mathrm{HB}+\mathrm{EG}$. This could be ascribed to the stronger interaction between the aromatic rings and the $\mathrm{BiOBr}$ surface [37], as confirmed by the aforementioned SPS spectra. These results strongly supported that the hydrogen bond-co- $\pi-\pi$ stacking was responsible for the formation of $\mathrm{BiOBr}$ microcubes.

Several additional experiments were conducted to confirm the above hypothesis. CTAB could not effectively achieve selective adsorption and hydrogen bond-co- $\pi-\pi$-stacking. When it was used instead of HB, only flower-like microspheres (Fig. S7(a) and (b)) of BiOBr were achieved due to the layer-by-layer structure [43]. When 1:1 mole ratio of $\mathrm{OB}$ or hb was used instead of $\mathrm{HB}, \mathrm{BiOBr}$ formed well-organized stacked microcubes (Fig. S7(c) and (f)). Interestingly, the shorter the branched (carbon) chain on the N1 (IL), the weaker was the stereospecific blockade. When a mixture of $\mathrm{HK}$ and $\mathrm{KBr}$ replaced $\mathrm{HB}$, $\mathrm{BiOBr}$ microcubes were obtained (Fig. S8(a) and (b)). Similarly, when a mixture of $\mathrm{HK}$ and $\mathrm{KCl}$ replaced $\mathrm{HB}, \mathrm{BiOCl}$ microcubes were achieved (Fig. S8(c) and (d)). More interestingly, when a mixture of $\mathrm{MI}$ and $\mathrm{KBr}$ was used instead of $\mathrm{HB}$, BiOBr microcubes was obtained even in the absence of an IL (Fig. S8(e) and (f)). These results further confirmed the key role of the hydrogen bond-co- $\pi-\pi$ stacking in BiOBr formation.

\subsection{Photocatalytic activity under visible light}

As shown in Fig. S9, both $\mathrm{BiOBr}$ and crushed BiOBr displayed type IV adsorption-desorption isotherms with a distinct hysteresis loop characteristic of a mesoporous structure. The
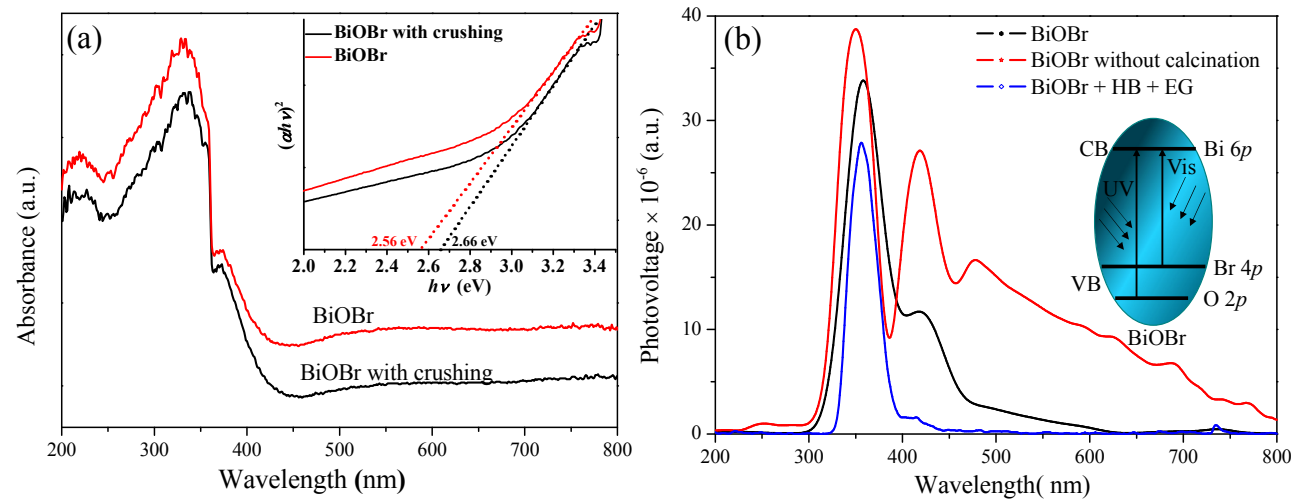

Fig. 4. (a) UV-vis DRS of BiOBr and crushed BiOBr; inset: optical bandgap of BiOBr. (b) Normalized SPS spectra of BiOBr, BiOBr without calcination, and $\mathrm{BiOBr}+\mathrm{EG}+\mathrm{HB}$; inset: bandgap structure of BiOBr. 

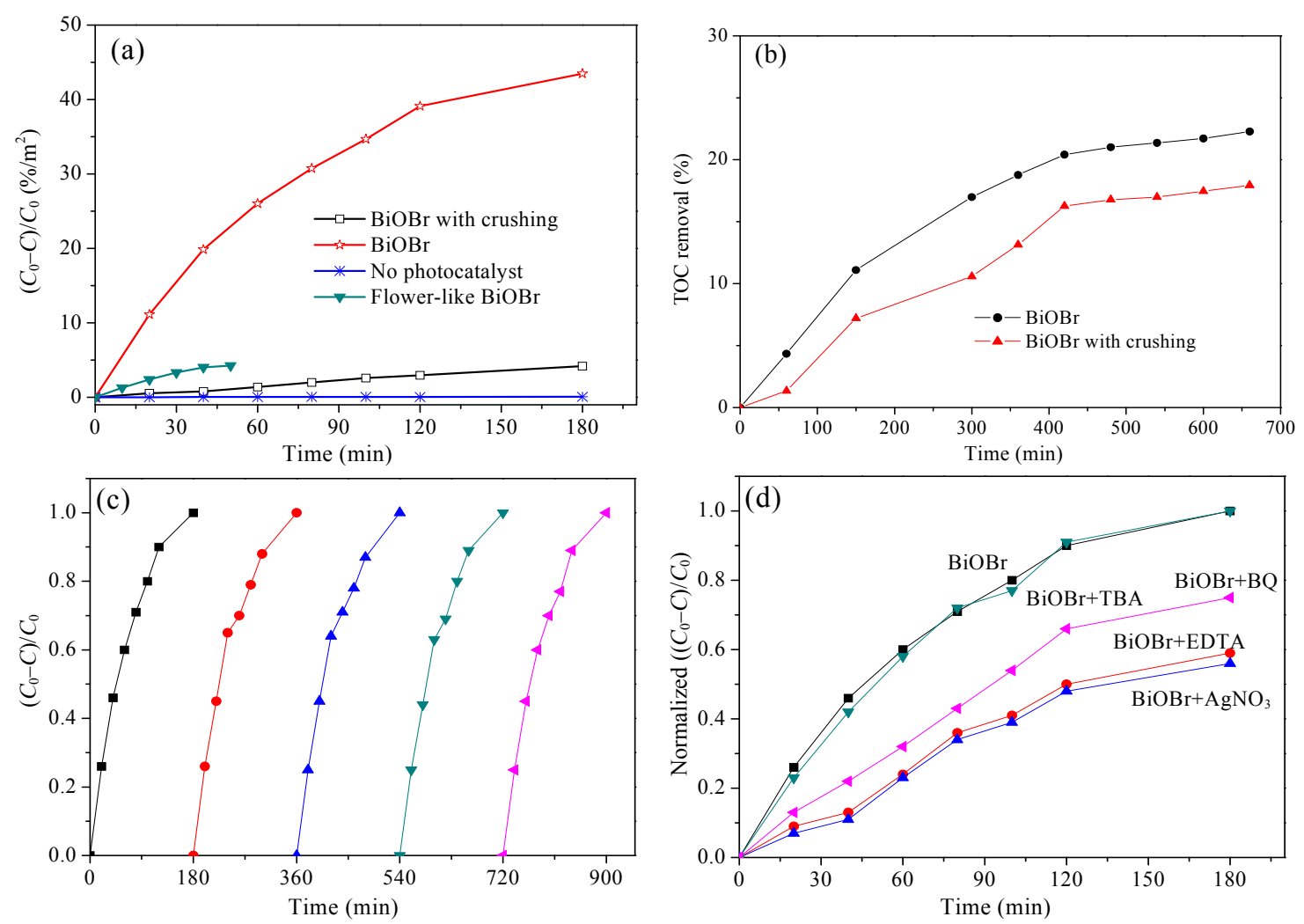

Fig. 5. (a) Comparison of different morphologies of BiOBr at the normalized specific surface area in the photocatalytic degradation of RhB under visible light; (b) TOC analysis of BiOBr and crushed BiOBr; (c) Reproducibility of BiOBr; (d) Effect of different trapping agents to investigate the role of active radicals in BiOBr catalyst. Reaction conditions: $100 \mathrm{~mL}$ RhB aqueous solution $10.0 \mathrm{mg} / \mathrm{L}, 25.0 \mathrm{mg}$ catalyst, $300 \mathrm{~W}$ Xe lamp ( $\lambda>420 \mathrm{~nm})$, and $T=$ $30^{\circ} \mathrm{C}$.

BET surface area of BiOBr was determined to be $2.30 \mathrm{~m}^{2} / \mathrm{g}$. After crushing, the BET surface area increased to $17.3 \mathrm{~m}^{2} / \mathrm{g}$ owing to the decreased particle size. From Fig. 5(a), we could see that no significant degradation in RhB occurred in the absence of a photocatalyst. Under visible light, $\mathrm{RhB}$ in the solution completely disappeared after 180 min of photocatalysis of $\mathrm{Bi}$ OBr. Although crushed BiOBr exhibited a much higher specific surface area than $\mathrm{BiOBr}$, its RhB degradation activity was far weaker $\left(3.97 \% / \mathrm{m}^{2}\right.$ versus $43.29 \% / \mathrm{m}^{2}$ or $68.68 \%$ versus $99.57 \%$ ). Such phenomena were also observed during the photocatalytic degradation of MO (Fig. S10). This indicated that the multistage reflection of nanosheets in the $\mathrm{BiOBr}$ microcube photocatalyst could increase light absorption, narrow the bandgap, and generate more photoelectrons and holes, leading to enhanced photocatalytic activity. The conversion rate at 180 min was about $99.57 \%\left(\sim 43.29 \% / \mathrm{m}^{2}\right)$, while the TOC removal (Fig. 5(b)) rate was only about $12.24 \%$. These results indicated that only a small fraction of RhB was completely degraded and mineralized in $\mathrm{CO}_{2}$. In addition, $\mathrm{BiOBr}$ showed superior photodegradation activity for RhB than flower-like BiOBr (BET surface area $=23.5 \mathrm{~m}^{2} / \mathrm{g}$, [21]), indicating that the microcubic Bi$\mathrm{OBr}$ mesocrystals facilitated charge transfer to improve the photocatalytic performance. Furthermore, BiOBr exhibited excellent stability, as shown in Fig. 5(c) with five recycles testing, which could be attributed to its highly crystalline nature that inhibited the decomposition of BiOBr. As is well known, because of the strong oxidizing ability of $\mathrm{Bi}^{3+}$ in Bi-based pho- tocatalysts such as $\mathrm{BiOX}(\mathrm{X}=\mathrm{Cl}, \mathrm{Br}, \mathrm{I}), \mathrm{BiVO}_{4}, \mathrm{Bi}_{2} \mathrm{WO}_{6}, \mathrm{Bi}_{2} \mathrm{MoO}_{6}$, $\mathrm{Bi}_{2} \mathrm{O}_{3}, \mathrm{Bi}_{2} \mathrm{~S}_{3}$, and bismuth titanate, they can be easily reduced to low valence states by photogenerated electrons. To confirm the stability of $\mathrm{Bi}^{3+}$ in $\mathrm{BiOBr}$, XPS characterization tests were employed (Fig. S11). The XPS peak position showed no obvious changes, further indicating the excellent stability of our $\mathrm{BiOBr}$ photocatalyst.

To investigate the mechanism of the photodegradation of $\mathrm{RhB}$, we used different trapping agents as scavengers, including ethylenediaminetetraacetic acid (EDTA), $\mathrm{AgNO}_{3}$, tert-butyl alcohol (TBA), and benzoquinone (BQ), and explored the effects of photo-induced holes $\left(\mathrm{h}^{+}\right)$, photogenerated electrons $\left(\mathrm{e}^{-}\right)$, hydroxyl radicals $(\cdot \mathrm{OH})$, and superoxide anions $\left(\mathrm{O}^{2-} \cdot\right)$ on the photocatalytic reaction system. Fig. 5(d) shows the effect of various sacrificial agents on the photocatalytic activity. It was found that the addition of TBA weakly influenced the photocatalytic degradation of $\mathrm{RhB}$, indicating that the active radical .OH did not play a key role in RhB degradation. When adding $\mathrm{BQ}$ to capture $\mathrm{O}^{2-}$. as another active radical into the reaction system, the photocatalytic activity did not significantly change. Furthermore, the addition of EDTA considerably decreased the photocatalytic degradation of RhB compared to pristine BiOBr. In particular, adding $\mathrm{AgNO}_{3}$ into the photocatalytic reaction system greatly reduced the degradation of $\mathrm{RhB}$. It could be concluded that the main active species were the photogenerated electrons, which reacted with dissolved $\mathrm{O}_{2}$ to produce $\mathrm{O}^{2-}$. and then oxidized pollutants. 


\section{Conclusions}

In summary, novel BiOBr microcubes were prepared by microwave-assisted IL self-assembly through hydrogen bond-co- $\pi-\pi$ stacking. The as-obtained $\mathrm{BiOBr}$ exhibited high activity in photocatalytic degradation of organic dyes under visible light owing to its narrow energy bandgap and strong light absorbance resulting from the multi-reflection of light within the microcubes. The main active species for the photodegradation of pollutants were photogenerated electrons. Furthermore, organic dyes could be completely mineralized, showing good potential for practical application in dye-wastewater cleaning.

\section{Acknowledgments}

We thank Dr. Xiao Wei from Shanghai Jiao Tong University for surface photovoltage spectrum.

\section{Author contributions}

Yingchun Miao and Zichao Lian performed the experiments; Yingchun Miao wrote this manuscript under the guidance of Prof. Hexing Li. All authors contributed to the general discussion and article revision.

\section{Conflict of interest}

The authors declare that they have no conflict of interest.

\section{Supporting information}

Supporting information is available in the online version of the paper.

\section{References}

[1] Y. J. Zhu, W. W. Wang, R. J. Qi, X. L. Hu, Angew. Chem. Int. Ed., 2004, $43,1410-1414$
[2] Y. Chen, W. Z. Li, J. Y. Wang, Y. L. Gan, L. Liu, M. T. Ju, Appl. Catal. B, 2016, 191, 94-105.

[3] N. V. Plechkova, K. R. Seddon, Chem. Soc. Rev., 2008, 37, 123-150.

[4] T. Welton, Chem. Rev., 1999, 99, 2071-2084.

[5] J. S. Xu, Y. J. Zhu, F. Chen, Mater. Lett., 2013, 94, 104-107.

[6] Z. Z. Liu, L. Qiao, H. Y. Gu, F. J. Yang, L. Yang, Sep. Purif. Technol., 2017, 172, 326-337.

[7] S. K. Li, X. Guo, Y. Wang, F. Z. Huang, Y. H. Shen, X. M. Wang, A. J. Xie, Dalton Trans., 2011, 40, 6745-6750.

[8] X. Li, D. Liu, S. Song, X. Wang, X. Ge, H. Zhang, Cryst. Eng. Commun., 2011, 13, 6017-6020.

[9] M. G. Ma, S. J. Qing, S. M. Li, J. F. Zhu, L. H. Fu, R. C. Sun, Carbohydr. Polym., 2013, 91,162-168.

[10] A. N. Dadhania, V. K. Patel, D. K. Raval, J. Saudi Chem. Soc., 2017, 21, S163-S169.

[11] S. W. Cao, Y. J. Zhu, G. F. Cheng, Y. H. Huang, J. Hazard. Mater., 2009, 171, 431-435.

[12] K. Ding, Z. J. Miao, Z. M. Liu, Z. F. Zhang, B. X. Han, G. M. An, S. D. Miao, Y. Xie, J. Am. Chem. Soc., 2007, 129, 6362-6363.

[13] J. S. Xu, Y. J. Zhu, Cryst. Eng. Commun., 2012, 14, 2630-2634.

[14] Y. C. Miao, G. F. Pan, Y. N. Huo, H. X. Li, Dyes Pigments., 2013, 99, 382-389.

[15] Z. C. Lian, W. C. Wang, G. S. Li, F. H. Tian, K. S. Schanze, H. X. Li, ACS Appl. Mater. Interfaces, 2017, 9, 16959-16966.

[16] H. Y. Si, C. J. Mao, Y. M. Xie, X. G. Sun, J. J. Zhao, N. Zhou, J. Q. Wang, W. J. Feng, Y. T. Li, Dalton Trans., 2017, 46, 200-206.

[17] H. Deng, J. W. Wang, Q. Peng, X. Wang, Y. D. Li, Chem. Eur. J., 2005, $11,6519-6524$.

[18] H. P. Li, T. X. Hu, J. Q. Liu, S. E. Song, N. Du, R. Zhang, W. Hou, Appl. Catal. B, 2016, 182, 431-438.

[19] Y. Wang, Z. Q. Shi, C. M. Fan, X. W. Wang, X. G. Hao, Y. Q. Chi, J. Solid State Chem., 2013, 199, 224-229.

[20] J. Xu, L. Li, C. S. Guo, Y. Zhang, S. F. Wang, Chem. Eng. J., 2013, 221, 230-237.

[21] Y. N. Huo, J. Zhang, M. Miao, Y. Jin, Appl. Catal. B, 2012, 111, 334-341.

[22] X. Zhang, Z. H. Ai, F. L. Jia, L. Z. Zhang, J. Phys. Chem. C, 2008, 112, 747-753.

[23] Z. D. Wei, R. Wang, Chin. Chem. Lett., 2016, 27, 769-772.

[24] Z. T. Deng, D. Chen, B. Peng, F. Q. Tang, Cryst. Growth Des., 2008, 8, 2995-3003.

[25] H. P. Li, T. X. Hu, N. Du, R. J. Zhang, J. Q. Liu, W. G. Hou, Appl. Catal.

\section{Graphical Abstract}

Chin. J. Catal., 2018, 39: 1411-1417 doi: 10.1016/S1872-2067(18)63080-3

Microwave-assisted ionothermal synthesis of hierarchical microcube-like $\mathrm{BiOBr}$ with enhanced photocatalytic activity

Yingchun Miao*, Zichao Lian, Yuning Huo, Hexing Li *

Qujing Normal University; Shanghai Normal University

$\mathrm{BiOBr}$ with hierarchical morphologies and hydrogen bond-co- $\pi-\pi$ stacking was successfully synthesized via microwave-assisted ionothermal self-assembly, and it exhibited high activity owing to the enhanced light absorbance and narrow bandgap.

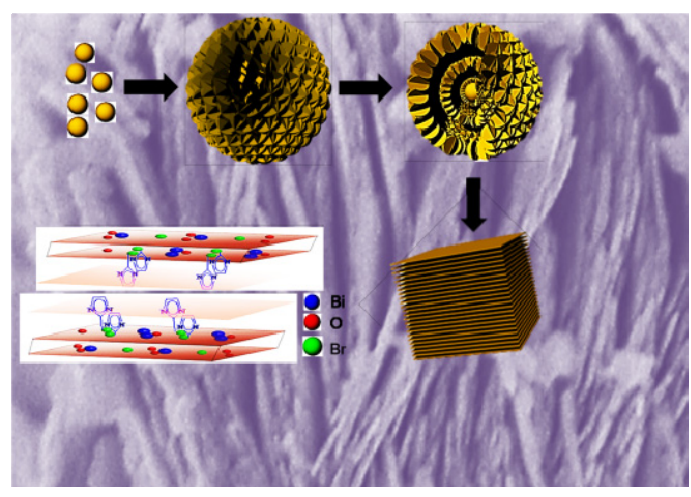


$B, 2016,187,342-349$.

[26] H. Cheng, B. Huang, Z. Wang, X. Qin, X. Zhang, Y. Dai, Chem. Eur. J., 2011, 17, 8039-8043.

[27] D. Q. Zhang, M. C. Wen, B. Jiang, G. S. Li, J. C. Yu, J. Hazard. Mater., 2012, 211, 104-111.

[28] Y. C. Feng, L. Li, J. W. Li, J. F. Wang, L. Liu, J. Hazard. Mater., 2011, 192, 538-544.

[29] X. J. Shi, X. Chen, X. L. Chen, S. M. Zhou, S. Y. Lou, Y. Q. Wang, L. Yuan, Chem. Eng. J., 2013, 222, 120-127.

[30] J. F. Zhang, J. X. Xia, S. Yin, H. M. Li, H. Xu, M. Q. He, L. Y. Huang, Q. Zhang, Colloids Surf., 2013, A 420, 89-95.

[31] J. F. Zhu, Y. J. Zhu, M. G. Ma, L. X. Yang, L. Gao, J. Phys. Chem. C, 2007, 111, 3920-3926.

[32] Y. Jiang, Y. J. Zhu, G. F. Cheng, Cryst. Growth. Des., 2006, 6, 2174-2176.

[33] Q. L. Tang, K. W. Wang, Y. J. Zhu, F. Chen, Mater. Lett., 2009, 63, 1332-1334.
[34] J. S. Xu, Y. J. Zhu, Mater. Lett., 2011, 65, 2793-2796.

[35] W. W. Wang, Y. J. Zhu, Inorg. Chem. Commun., 2004, 7, 1003-1005.

[36] X. L. Hu, Y. J. Zhu, S. W. Wang, Mater. Chem. Phys., 2004, 88, 421-426.

[37] J. B. Lian, X. C. Duan, J. M. Ma, P. Peng, T. L. Kim, W. J. Zheng, ACS Nano., 2009, 3, 3749-3761.

[38] X. F. Chang, J. Huang, C. Cheng, Q. Sui, W. Sha, G. B. Ji, S. B. Deng, G. Yu, Catal. Commun., 2010, 11, 460-464.

[39] J. Zhang, F. J. Shi, J. Lin, D. F. Chen, J. M. Gao, Z. X. Huang, X. X. Ding, C. C. Tang, Chem. Mater., 2008, 20, 2937-2941.

[40] Z. H. Ai, W. Ho, S. Lee, L. Z. Zhang, Environ. Sci. Technol., 2009, 43, 4143-4150.

[41] Y. F. Fang, W. H. Ma, Y. P. Huang, G. W. Cheng, Chem. Eur. J., 2013, 19, 3224-3229.

[42] W. Zheng, X. Liu, Z. Yan, L. Zhu, ACS Nano, 2009, 3, 115-122.

[43] G. H. Tian, Y. J. Chen, W. Zhou, K. Pan, Y. Z. Dong, C. G. Tian, H. G. Fu, J. Mater. Chem., 2011, 21, 887-892.

\title{
微波辅助离子热合成具有高光催化活性的 BiOBr 片层微米立方体
}

\author{
缪应纯 $a, b,{ }^{*}$, 廉志超 ${ }^{b}$, 霍宇凝 ${ }^{b}$, 李和兴 $b$, \# \\ a曲靖师范学院资源与环境化学重点实验室, 云南曲靖 655400 \\ b 上海师范大学上海市稀土功能材料重点实验室, 上海 200234
}

摘要: 微波辅助离子热合成技术因其加热和反应速度快、反应时间短、产物选择性高、环保、节能等优点, 而广泛应用于 纳米棒、纳米线和中空纳米微球等各种形貌功能材料的合成. BiOBr 光催化剂具有毒性低、光生空穴氧化能力强、光降解 活性高等优点, 在光催化降解污染物方面研究非常广泛. 虽然各种形貌的 BiOBr 光催化剂可以通过传统的溶剂热法合成, 但仍然需要开发绿色和高效节能的合成方法, 来设计新型结构和高光催化降解活性的 $\mathrm{BiOBr}$ 光催化剂. 本文首次报道了 由微波辅助离子热自组装的方法合成新型结构的 $\mathrm{BiOBr}$ 微米立方体. 该 $\mathrm{BiOBr}$ 由规则的多层纳米片组成, 其通过在 $\mathrm{Br}$-端 表面上选择性吸附离子液体形成, 随后形成氢键的 $\pi-\pi$ 堆叠. 结果显示 $\mathrm{BiOBr}$ 是由厚度小于 $50 \mathrm{~nm}$ 的纳米片组装成为 4 $\mu \mathrm{m}$ 左右的纳米立方块. 其中 Bi:Br:O 摩尔比为 $1: 1: 1$, 表明生成纯化学计量比的 $\mathrm{BiOBr}$, 且具有高结晶度的纯四方相. 我们 通过添加不同的表面活性剂, 进一步确认氢键-co- $\pi-\pi$ 叠层在 BiOBr 片层立方块形成中的重要性.

将 $\mathrm{BiOBr}$ 片层立方块研磨粉碎后其 $\mathrm{BET}$ 表面积为从 2.30 急剧增至 $17.3 \mathrm{~m}^{2} / \mathrm{g}$, 但其降解 $\mathrm{RhB}$ 活性却大幅度下降. 由 于纳米片层的层间反射和散射, 有效地提升了 $\mathrm{BiOBr}$ 的可见光吸收, 光学带隙由 2.66 窄化为 $2.56 \mathrm{eV}$, 因而具有高的可见 光光降解活性和优异的稳定性及矿化能力. 光催化降解 $180 \mathrm{~min}$ 后, 罗丹明 B 的转化率约为 $99.57 \%$, 而有机碳去除率高达 $12.24 \%$; 对于磨碎的 BiOBr 罗丹明 B 的转化率和有机碳去除率分别为 $68.68 \%$ 和 $8.62 \%$. 光催化反应前后的 $\mathrm{BiOBr}$ 中, $\mathrm{Bi}^{3+}$ 离子的 XPS 峰位置没有明显的变化, 进一步表明 $\mathrm{BiOBr}$ 光催化剂具有较高的稳定性. 这种具有高活性、优异的稳定性 以及高矿化能力的 $\mathrm{BiOBr}$, 在实际应用光催化降解染料废水和清洁能源方面显示出很好的潜力. 此外, 通过光催化反应过 程中不同捕获剂的添加确定了光降解的主要活性物种. 当加入硝酸银溶液的时候, 由于光生电子快速被 $\mathrm{Ag}^{+}$离子捕获, 光 降解活性明显下降. 活性物种的捕获实验表明, 光生电子为主要的活性物种.

关键词: 微波; $\mathrm{BiOBr}$ 片状立方体; 自组装; 光催化降解; 矿化能力

收稿日期: 2018-03-03. 接受日期: 2018-04-25. 出版日期: 2018-08-05.

*通讯联系人. 电子信箱: miaoyingchun1979@sohu.com

\#通讯联系人. 电子信箱: hexing-li@shnu.edu.cn

基金来源：国家自然科学基金 (20937003, 21261140333, 21237003, 21207091, 21577092, 2171101231); 上海市政府项目 (12230706000, 11JC1409000, 12YZ091, 15520711300); 云南省应用基础研究项目(2013FZ109, 2016FB016); 云南省教育部门重点 项目 (2015Z183, 2016ZZX207).

本文的电子版全文由Elsevier出版社在ScienceDirect上出版(http://www.sciencedirect.com/science/journal/18722067). 